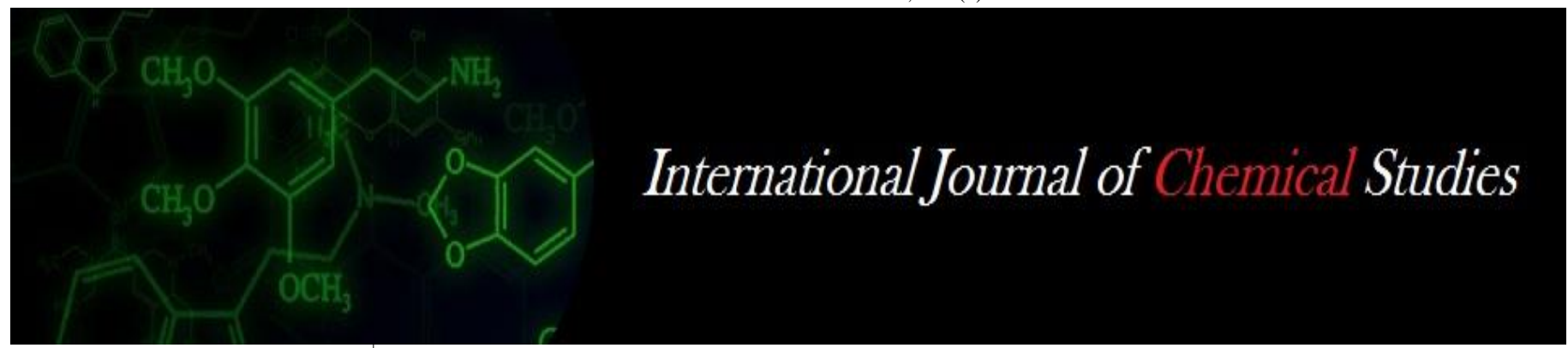

P-ISSN: 2349-8528

E-ISSN: 2321-4902

www.chemijournal.com

IJCS 2020; SP-8(3): 286-289

(C) 2020 IJCS

Received: 29-04-2020

Accepted: 30-05-2020

Kanta Sabharwal

DES (Home Science), CCS HAU,

Krishi Vigyan Kendra, Bhiwani,

Haryana, India

Candy

Research Associate, COHS,

CCSHAU, Hisar, Haryana, India

Yogita

DES, Agronomy, K VK,

Bhiwani, Haryana, India

Beena Yadav

Professor \& Head, Deptt. of

EECM, COHS, CCSHAU, Hisar,

Haryana, India
Corresponding Author:

Kanta Sabharwal Candy

DES (Home Science), CCS HAU,

Krishi Vigyan Kendra, Bhiwani,

Haryana, India

\section{A study on Awareness and use pattern of Information and Communication Technology among rural farmers}

\author{
Kanta Sabharwal, Candy, Yogita and Beena Yadav
}

DOI: https://doi.org/10.22271/chemi.2020.v8.i4e.10045

\begin{abstract}
Information and communication technology is a set of tools that are used in rural areas for the development of villagers and farmers. ICT include computer hardware, computer software, radio, television, mobile phones, digital camera and other application software's that are used for agriculture sector. The development in rural areas has been increased as compared to previous years. The farmers now used techniques and procedures to enhanced their products and maintain the cost and quality of their products. ICT also provide the training to the farmers/ farm women entrepreneurs who want to run their small business by availing the credit facilities through various training institutes of Banks (Mir and Kumar, 2017). Nowadays ICTs are playing a focal role in the development process of any country. In today's life Technology became a part of life and livelihood. In this digital era, India is using ICTs to promote their development programs as well as reaches to the poor to strengthen their lively hood (Kumar and Maheshwary, 2015). Considering these facts the study was conducted in Hisar district with objectives to study the inter-gender analysis on ownership of mobile phone, reason for having a mobile phone and awareness and use of different ICT tools and services. Results revealed that 100.00 percent of male respondents and 64.00 percent of female respondents have possessed their own mobile phone. 38.00 percent of male respondents and 47.00 percent of the female respondents had mobile without internet connection whereas 62.00 percent of male respondents and 17.00 percent of female respondents having mobile with internet connection. Majority of respondents have given the reason for having a mobile phone that phone was required for connecting with relatives and friends followed by listening music and social networking. 100.00 percent of male and 89.00 percent of female respondents who were having mobile phone without internet connection were aware of making calls and 100.00 percent of male and $61.00 \%$ female respondents were using mobile phone without internet connection for calling. Respondents having mobile phone with internet connection, majority of male respondents $(72.00 \%)$ reported that they were aware of memory stick followed by making calls and Games/ movies/ songs (70.00\%), Music/ Photography and SMS (58.00\%). In case of female 84.00 percent of female respondents were aware of making calling followed by use of memory stick (56.00\%), games and movies $(53.00 \%)$ and SMS $(51.0 \%)$. Only 22.00 percent of male and 2.00 percent of female respondents had account on Facebook and also assessed different internet sites for educational purposes.
\end{abstract}

Keywords: Information and communication technology, Awareness and Use

\section{Introduction}

Information and communication technology is a set of tools that are used in rural areas for the development of villagers and farmers. ICT include computer hardware, computer software, radio, television, mobile phones, digital camera and other application software's that are used for agriculture sector. The development in rural areas has been increased as compared to previous years. The farmers now used techniques and procedures to enhanced their products and maintain the cost and quality of their products. ICT also provide the training to the farmers/ farm women entrepreneurs who want to run their small business by availing the credit facilities through various training institutes of Banks (Mir and Kumar, 2017) ${ }^{[4]}$. In a developing economy like India, ICT has developed an education, health, human right promotion, communication, economic growth and goverence and other areas (Tripathi et al. 2012) ${ }^{[7]}$. ICTs are playing a focal role in the development process of any country. In today's life Technology became a part of life and livelihood. In this digital era, India is using ICTs to promote their development programs as well as reaches to the poor to strengthen their lively 
hood (Kumar and Maheshwary, 2015) ${ }^{[2]}$. ICT can facilitate speedy, transparent, accountability, efficient and effective interaction between the public, citizens, business and other agencies. It was the situation when we want to send a letter or message, many days were required. Today, e-mail facility, social media have made it possible to cover a large distance in very small time. ICT as an enabler has broken all bounds of cost, distance and time (Rajamohan and Dhanabalan, 2013) ${ }^{[6]}$. In rural areas, one cyber is sufficient to make the rural citizens known to ICT. The ICT kiosk movement has been able to create a stir in local communication in terms of knowledge and know-how about the use of technology for accessing information and using it as a better livelihood. (Naryanan and Gaurav, 2009) ${ }^{[5]}$. Considering these facts the study was conducted in Hisar district with objectives to study the inter-gender analysis on ownership of mobile phone, reason for having a mobile phone and awareness and use of different ICT tools and services.

\section{Methodology}

Research work was carried out in Hisar district of Haryana state. Two blocks viz. Hisar-I and Hisar -II were selected randomly. Out of these two blocks, five villages namely Mangali and Kaimari from Hisar-I block and Ludas, Tokas and Singhran from Hisar-II block were selected under AICRP project. A list of farming families with ICT usage in selected villages was prepared after discussion with Anganwadi workers, helpers and key leaders. Thus a total 200 respondents
(100 female and 100 male farmers) preferably from same family were selected who had access to mobile. Data were collected personally on inter-gender analysis on ownership of mobile phone, reason for having a mobile phone and awareness and use of different ICT tools and services. Intergender qualitative data were analyzed and interpreted to draw meaningful inferences through percentage.

\section{Results and Discussion}

\section{Organizational participation by gender}

The results in Table 1 regarding organizational participation revealed that only 4.00 percent of female and 2.00 percent of male respondents had occasionally participated in Self Help Groups followed by 2.00 percent of female respondents who were regularly participated in Self Help Groups. All the respondents never participated in any programmes organized by Mahila Mandal, Zila panchayat and Taluk panchayat.

Table 1: Percent distribution of respondents according to organizational participation $\mathrm{N}=200(100$ male +100 female $)$

\begin{tabular}{|c|c|c|c|c|c|c|}
\hline \multirow{3}{*}{ Organization } & \multicolumn{6}{|c|}{ Extent of participation } \\
\cline { 2 - 7 } & Regularly & Occasionally & \multicolumn{2}{c|}{ Never } \\
\hline & Male & Female & Male & Female & Male & Female \\
\hline Self Help Group & - & 2.00 & 0.00 & 4.00 & 100.00 & 94.00 \\
\hline Anganwadi centre & - & 18.00 & 00.00 & 23.00 & 100.00 & 59.00 \\
\hline Mahilamandal & - & & - & - & 100.00 & 100.00 \\
\hline Gram Panchayat & 3.00 & 1.00 & 4.00 & 3.00 & 93.00 & 96.00 \\
\hline Zila panchayat & - & - & - & - & 100.00 & 100.00 \\
\hline Taluk panchayat & - & - & - & - & 100.00 & 100.00 \\
\hline
\end{tabular}

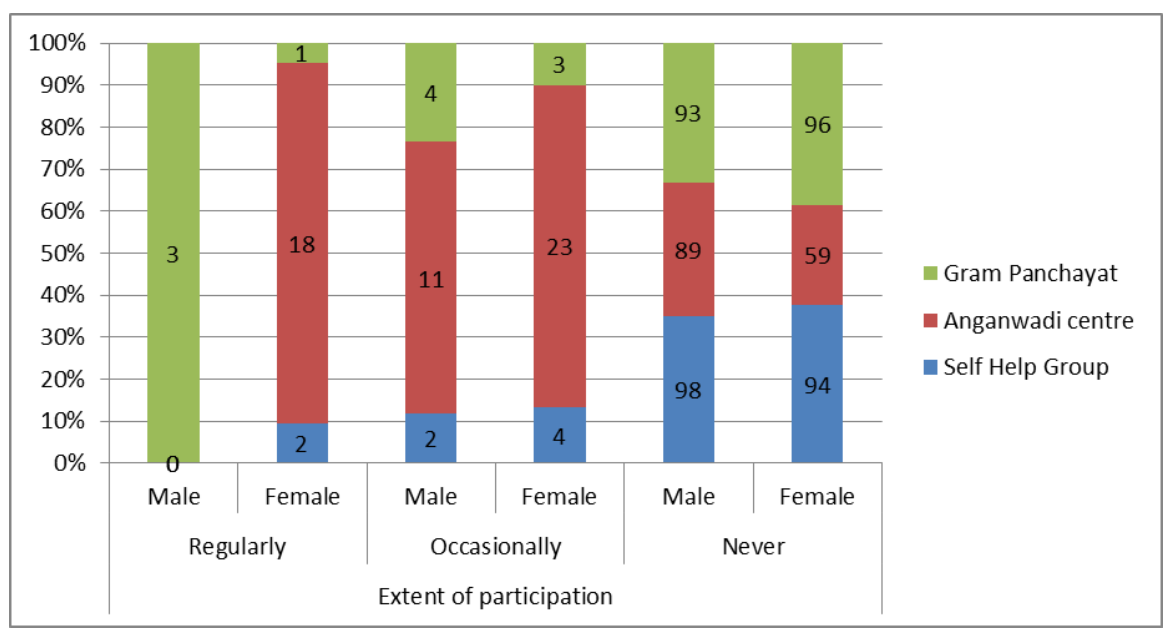

Fig. 1: Percent distribution of respondents according to organizational participation

Extension contact of the respondents: The data regarding extension contact in Table 2 revealed that 46.00 percent of male respondents had regular extension contact with Bank personnel followed by VLEW (29.00\%), university personnel $(27.00 \%)$ and extension officers $(24.00 \%)$. Whereas 19.00 percent of female respondents had regular extension contact with extension officers followed by university personnel
$(15.00 \%)$ and VLEW (12.00\%). On the other hand 66.00 percent of male respondents and 64.00 percent of female respondents had occasional extension contact with university personnel as they have attended different trainings, kisan mela and other programmes which were organized by university personnel from time to time.

Table 2: Percent distribution of respondents according extension contact $N=200(100$ male +100 female)

\begin{tabular}{|c|c|c|c|c|c|c|}
\hline \multirow{2}{*}{ Extension Contacts } & \multicolumn{2}{|c|}{ Regularly } & \multicolumn{2}{c|}{ Occasionally } & \multicolumn{2}{c|}{ Never } \\
\cline { 2 - 7 } & Male & Female & Male & Female & Male & Female \\
\hline VLEW & 29.00 & 12.00 & 57.00 & 31.00 & 14.00 & 57.00 \\
\hline Extension Officer/ KVK Scientist & 24.00 & 19.00 & 52.00 & 35.00 & 19.00 & 46.00 \\
\hline University Personnel & 27.00 & 15.00 & 66.00 & 64.00 & 7.00 & 21.00 \\
\hline NGO Personnel & 4.00 & 11.00 & 20.00 & 33.00 & 76.00 & 56.00 \\
\hline Bank Personnel & 46.00 & 10.00 & 54.00 & 36.00 & - & 54.00 \\
\hline Block Personnel & 12.00 & 9.00 & 43.00 & 25.00 & 45.00 & 66.00 \\
\hline
\end{tabular}


Ownership of mobile phone: As far as ownership of mobile is concerned, Table-3 describes that hundred percent of male respondents and 64.00 percent of female respondents have possessed their own mobile phone.

Table 3: Percent distribution of respondents according to their ownership of mobile $\mathrm{N}=200$ (100 male+100 female)

\begin{tabular}{|c|c|}
\hline \multicolumn{2}{|c|}{ Ownership of mobile } \\
\hline Male & Female \\
\hline 100.00 & 64.00 \\
\hline
\end{tabular}

Reasons for owning a mobile phone by gender: It is clear from the table- 4 that 38.00 percent of male respondents and 47.00 percent of the female respondents had mobile without internet connection whereas 62.00 percent of male respondents and 17.00 percent of female respondents having mobile with internet connection. Table further revealed the reason for owning a mobile phone that all the respondents reported that phone was required for connecting with relatives and friends followed by listening music and social networking.

Table 4: Percent distribution of respondents according to their reasons for owning a mobile phone $\mathrm{N}=200$ (100 male+100 female)

\begin{tabular}{|c|c|c|c|c|}
\hline \multirow{2}{*}{ Statements } & \multicolumn{2}{|c|}{$\begin{array}{c}\text { Respondent } \\
\text { without internet }\end{array}$} & \multicolumn{2}{c|}{$\begin{array}{c}\text { Respondent with } \\
\text { internet }\end{array}$} \\
\cline { 2 - 5 } & $\begin{array}{c}\text { Male } \\
(\mathbf{N = 3 8})\end{array}$ & $\begin{array}{c}\text { Female } \\
(\mathbf{N = 4 7 )}\end{array}$ & $\begin{array}{c}\text { Male } \\
(\mathbf{N = 6 2})\end{array}$ & $\begin{array}{c}\text { Female } \\
(\mathbf{N = 1 7 )}\end{array}$ \\
\hline Prestige/status & 0.00 & 3.00 & 6.00 & 5.00 \\
\hline Other women have it & 0.00 & 0.00 & 0.00 & 0.00 \\
\hline $\begin{array}{c}\text { Other family members have } \\
\text { it }\end{array}$ & 2.00 & 6.00 & 0.00 & 2.00 \\
\hline It was gifted & 0.00 & 0.00 & 1.00 & 3.00 \\
\hline $\begin{array}{c}\text { It is required for connecting } \\
\text { with relatives/friends }\end{array}$ & 38.00 & 47.00 & 62.00 & 17.00 \\
\hline Social networking & 0.00 & 0.00 & 35.00 & 12.00 \\
\hline Seeking information & 4.00 & 2.00 & 26.00 & 6.00 \\
\hline Music/ Photography & 15.00 & 27.00 & 12.00 & 14.00 \\
\hline \multicolumn{4}{|c|}{}
\end{tabular}

\section{Awareness \& use of different ICT tools \& services}

Data presented in table-5 regarding awareness and use of ICT tools and services revealed that 100.00 percent of male and 89.00 percent of female respondents who were having mobile phone without internet connection were aware of making calls followed by memory stick $(73.00 \%$ male \& $56.00 \%$ female) and listening music $(69.00 \%$ and $40.00 \%)$. As far as use of mobile phone is concerned table further shows that 100.00 percent of male respondents were using mobile phone without internet connection for calling followed by SMS $(54.00 \%)$ and use of memory stick $(44.00 \%)$. In case of female 61.00 percent of female respondents were using without internet mobile for calling followed by music, photography $(26.00 \%)$ and use of memory stick $(24.00 \%)$.

Respondents having mobile phone with internet connection, majority of male respondents $(72.00 \%)$ reported that they were aware of memory stick followed by making calls and Games/movies/songs (70.00\%), Music/Photography and SMS $(58.00 \%)$. In case of female 84.00 percent of female respondents were aware of making calling followed by use of memory stick $(56.00 \%)$, games and movies $(53.00 \%)$ and SMS (51.0\%). Results are comparable with Hasan et al . (2019) ${ }^{[1]}$ that 23.7 percent farmers had moderate awareness on use of ICT in farm practices while 60 percent and 12.7 percent of the farmers had low and very low awareness on use of ICT based facilities in their farm practices. Table further revealed the use of mobile phone with internet connection results revealed that 62.00 percent of male and 39.00 percent of female respondents were using phone for making calls, followed by use of memory stick/ card (45.00 \& 26.00) and SMS $(45.00 \% \& 22.00 \%)$. Only 22.00 percent of male and 2.00 percent of female respondents had account on Facebook and also assessed different internet sites for educational purposes. It is evident from table that 45.00 percent of male and 42.00 percent of female respondents were aware for making presentation and only 8.00 and 3.00 percent of male and female respondents were using computers for preparation of presentation and playing games on computer without internet. None of the respondents found, who were using, computer with internet connection. Results are inconsonance with Lokeshwari, $2016^{[3]}$ who says that more young farmers are getting involved in making use of ICT services, for agricultural information, they were functionally literate. Farmers use the ICT frequently as and when they needed information. It was observed that exposure of farmers to mass media was found conducive to utilization of ICT by the farmers.

Table 5: Percent distribution of respondents according to their Awareness \& use of different ICT tools \& services N=200 (100 male+100 female)

\begin{tabular}{|c|c|c|c|c|}
\hline \multirow{2}{*}{ ICT tools and services } & \multicolumn{2}{|c|}{ Aware } & \multicolumn{2}{c|}{ Use } \\
\cline { 2 - 5 } & Male & Female & Male & Female \\
\hline Mobile without internet \\
\hline Calling & 100.00 & 89.00 & 100.00 & 61.00 \\
\hline SMS & 62.00 & 51.00 & 54.00 & 19.00 \\
\hline Memory stick & 73.00 & 56.00 & 44.00 & 24.00 \\
\hline Music/ Photography & 69.00 & 40.00 & 42.00 & 26.00 \\
\hline Mobile with internet \\
\hline Calling & 70.00 & 84.00 & 62.00 & 39.00 \\
\hline SMS & 58.00 & 51.00 & 45.00 & 22.00 \\
\hline Whats app & 72.00 & 56.00 & 45.00 & 26.00 \\
\hline Facebook & 51.00 & 38.00 & 33.00 & 23.00 \\
\hline Memory stick/ Memory card & 31.00 & 20.00 & 6.00 & 2.00 \\
\hline Games/ movies/ songs & 70.00 & 53.00 & 35.00 & 17.00 \\
\hline Accessing different internet sites & 41.00 & 22.00 & 22.00 & 2.00 \\
\hline Music/ Photography & 58.00 & 26.00 & 35.00 & 22.00 \\
\hline Computer /laptop without internet \\
\hline Office documents/presentations etc. & 19.00 & 42.00 & 8.00 & 3.00 \\
\hline Music/ Photography & 21.00 & 42.00 & 10.00 & 3.00 \\
\hline Computer/laptop with internet \\
\hline Office documents/presentations etc. & 19.00 & 42.00 & 0.00 & 100.00 \\
\hline Facebook, social media & 18.00 & 42.00 & 0.00 & 100.00 \\
\hline Accessing different internet sites & 19.00 & 42.00 & 0.00 & 100.00 \\
\hline Music/ Photography & 22.00 & 42.00 & 0.00 & 100.00 \\
\hline
\end{tabular}

\section{Conclusion}

The findings revealed that all the male respondents and more than sixty percent of female respondents have possessed their own mobile phone. Majority of respondents have given the reason for having a mobile phone that phone was required for connecting with relatives and friends followed by listening music and social networking. All male and more than eighty five percent female respondents who were having mobile phone without internet connection were aware of making calls. Only 22.00 percent of male and 2.00 percent of female respondents had account on Facebook and also assessed different internet sites for educational purposes.

\section{References}

1. Hasan F, Rahman MH, Hoque J, Kamruzzaman M, Rahaman K, Azizur MD et al . Farmers awareness on use 
of ICT in farm practices. Asian Australas Journal of Biosci. Biotechnology. 2019; 4(1):34-47.

2. Kumar, Maheshwary. Impact of Information Communication Technology for Development and Digital Era: A Literature Review. Int. J. of Research in Electronics and Computer Engineering. 2015; 3(3):126128.

3. Lokeshwari K. A study of the use of ICT among rural farmers. Internation journal of Chemical research. 2016; 6(3):223-238

4. Mir AW, Kumar R. A study on role and application of ICT in development of rural areas. Int. J. Of Scientific Research and Management. 2017; 5(8):6758- 6763.

5. Narayanan A, Chakraverty G. Running ICT telecentres in rural India. International Journal of Innovative Research in Computer and Communication Engineering. 2009; 19(1):21-31.

6. Rajamohan S, Dhanabalan. Rural development through ICT: Opportunities and Challenges. International Journal of Innovative Research in Computer and Communication Engineering. 2013; 2(1):354-358

7. Tripathi AM, Singh AK, Kumar A. Information and Communication technology for rural development. Int. J. of Computer Science. and Engineering. 2012; 4(5):824828. 